\title{
Mucosal Melanoma of the Head and Neck Clinical TNM Finding v8
}

National Cancer Institute

\section{Source}

National Cancer Institute. Mucosal Melanoma of the Head and Neck Clinical TNM Finding

v8. NCI Thesaurus. Code C133169.

A clinical finding about one or more characteristics of mucosal melanoma of the head and neck, following the rules of the TNM AJCC v8 classification system. 